\title{
Titanosilicate Molecular Sieve for Size-Screening Photocatalytic Conversion
}

Yasuhiro Shiraishi, ${ }^{*}$ Naoya Saito, and Takayuki Hirai

Research Center for Solar Energy Chemistry, and Division of Chemical Engineering,

Graduate School of Engineering Science, Osaka University, Toyonaka 560-8531, Japan

\section{Supporting Information}

\section{Materials and Methods}

\section{Catalyst Preparation}

TS-1. This was synthesized according to the literature procedure, ${ }^{1}$ as follows: a mixture of $0.39 \mathrm{~g}$ of tetraethyl orthotitanate (TEOT) and $18 \mathrm{~g}$ of tetraethyl orthosilicate (TEOS) was added to $40 \mathrm{~mL}$ of tetrapropyl ammonium hydroxide (20\% aqueous solution) with stirring. The mixture was kept at $333 \mathrm{~K}$ for $3 \mathrm{~h}$, where distilled water was added intermittently to compensate for the evaporation. The resulting mixture was transferred into a stainless steel autoclave and heated at $448 \mathrm{~K}$ for $24 \mathrm{~h}$ under static condition. The solid obtained was recovered by filtration, washed thoroughly with distilled water, dried at $373 \mathrm{~K}$ for $2 \mathrm{~h}$, and finally calcined at $823 \mathrm{~K}$ for $5 \mathrm{~h}$ under air flow, affording white powder.

TS-2. This was synthesized according to the literature procedure, ${ }^{2}$ as follows: $0.49 \mathrm{~g}$ of tetrabutyl orthotitanate dissolved in dry 2-propanol $(10 \mathrm{~mL})$ was added to a mixture of $15 \mathrm{~g}$ of TEOS and $30 \mathrm{~mL}$ of tetrabutyl ammonium hydroxide (20\% aqueous solution) with stirring. The obtained liquid was stirred at room temperature for $0.5 \mathrm{~h}$ and then at $353 \mathrm{~K}$ for $2 \mathrm{~h}$. The resultant was transferred into a stainless steel autoclave and heated at $443 \mathrm{~K}$ for $48 \mathrm{~h}$ under static condition. The solid obtained was recovered by filtration, washed thoroughly with distilled water, dried at $373 \mathrm{~K}$ for $6 \mathrm{~h}$, and finally calcined at $823 \mathrm{~K}$ for $16 \mathrm{~h}$ under air flow, affording white powder.

$\mathrm{TiO}_{2}$ (anatase). This was supplied from Wako Pure Chemical Industries, Ltd, which was used for photocatalytic reactions after drying at $423 \mathrm{~K}$ for $12 \mathrm{~h}$ under vacuum.

$\mathrm{TiO}_{2} / \mathrm{S}-1$. Pure silicious silicalite-1 (S-1; Table S1) was prepared in the same manner as TS-1, 
where no Ti source was added. The impregnation of $\mathrm{TiO}_{2}$ onto the surface of S-1 was carried out according to the literature procedure, ${ }^{3}$ as follows: The S-1 ( 1 g) was suspended in $n$-hexane $/ n$-heptane mixture $(1 / 1 \mathrm{v} / \mathrm{v}$; total $40 \mathrm{~mL})$ and dispersed finely by ultrasonication. TEOT $(0.076 \mathrm{~g})$ was added slowly to the mixture with stirring at room temperature. After stirring for $1 \mathrm{~h}$, solvents were removed from the mixture by evaporation. The obtained solid was dried at $373 \mathrm{~K}$ for $2 \mathrm{~h}$ and calcined at $823 \mathrm{~K}$ for $6 \mathrm{~h}$ under air flow, affording white powder.

TS-1 ${ }^{\text {high }}$. This was synthesized in the same manner as TS-1, where the amount of TEOT added was $1.1 \mathrm{~g}$.

Ti-SiO $\mathbf{O}_{2}$. This was synthesized according to the literature procedure, ${ }^{4}$ as follows: a mixture of TEOS (21 g), ethanol (17 g), distilled water (1.8 g), and concentrated nitric acid (0.89 $\mathrm{g})$ was stirred at $353 \mathrm{~K}$ for $3 \mathrm{~h}$ and then cooled to room temperature. A solution of $0.057 \mathrm{~g}$ of tetraisopropyl orthotitanate dissolved in dry 2-propanol $(10 \mathrm{~mL})$ was added slowly to the mixture and stirred for $2 \mathrm{~h}$ at room temperature. An aqueous solution $(21 \mathrm{~g})$ of nitric acid (ca. $3.5 \mathrm{M})$ was then added very slowly, and the mixture kept static for two weeks. The obtained gel was heated at a rate of $0.2 \mathrm{~K} / \mathrm{min}$ up to $338 \mathrm{~K}$ and kept for $5 \mathrm{~h}$. The obtained solid was dried at $373 \mathrm{~K}$ for $5 \mathrm{~h}$ and finally calcined at $773 \mathrm{~K}$ for $8 \mathrm{~h}$ under air flow, affording white powder.

\section{Photocatalytic Reaction}

Each catalyst $(10 \mathrm{mg})$ was suspended in distilled water $(10 \mathrm{~mL})$ containing an individual substrate $(20 \mu \mathrm{mol})$ within a Pyrex glass tube (capacity: $20 \mathrm{~mL})$, and each tube sealed using a rubber septum cap. The catalyst was dispersed well by ultrasonication for 5 min. Oxygen was bubbled through the solution for 10 min and photoirradiated with stirring by a high-pressure $\mathrm{Hg}$ lamp (300 W, Eikohsha Co. Ltd., Osaka), filtered through a Pyrex glass to give light wavelengths of $\lambda>280 \mathrm{~nm}$. It was confirmed that all of the substrates used scarcely absorb the light at this wavelength range. The temperature of the solution during photoirradiation was $313 \mathrm{~K}$. The resulting solution was recovered by filtration, and the concentrations of substrates and products were determined by a reverse-phase HPLC (Shimadzu LC-6A) equipped with UV-vis 
spectrometric detector (Shimadzu SPD-6A), where the detection wavelength of $254 \mathrm{~nm}$ was employed.

\section{ESR Measurement}

General. ESR spectra were recorded at the X-band using a Bruker EMX-10/12 spectrometer with a $100 \mathrm{kHz}$ magnetic field modulation at a microwave power level of $1.0 \mathrm{~mW}$, where microwave power saturation of the signals does not occur. The magnetic field was calibrated using a 1,1'-diphenyl-2-picrylhydrazyl (DPPH) as standard. Photoirradiation of the samples was carried out using a $500 \mathrm{~W}$ Xe lamp (USHIO Inc.).

Measurement in the presence of substrates (Figure 3). All of the spectra were recorded with photoirradiation. Each TS-1 and $\mathrm{Ti}_{-}-\mathrm{SiO}_{2}$ catalyst $(50 \mathrm{mg})$ was placed in a quartz ESR tube and treated with 100 Torr oxygen $(1$ Torr $=133.3 \mathrm{~Pa})$ at $773 \mathrm{~K}$ for $12 \mathrm{~h}$. The tube was evacuated at 673 $\mathrm{K}$ for $1 \mathrm{~h}$ and then at $77 \mathrm{~K}$ for $1 \mathrm{~h}$. The tube was placed on an ESR sample cavity and photoirradiated at $77 \mathrm{~K}$. After photoirradiation for $0.5 \mathrm{~h}$, measurement was then started at this conditions (spectrum i). The sample was then warmed to room temperature under evacuation. The sample was placed in a glove box filled with $\mathrm{Ar}$, and deaerated $\mathrm{H}_{2} \mathrm{O}(50 \mu \mathrm{L} ; 2.8 \mathrm{mmol})$ was added by a syringe at room temperature. The sample was evacuated at $77 \mathrm{~K}$ for $1 \mathrm{~h}$. The spectra were then recorded in the same manner at $77 \mathrm{~K}$ with photoirradiation (spectrum ii). The sample was then evacuated at $673 \mathrm{~K}$ for $1 \mathrm{~h}$ and cooled to room temperature for $1 \mathrm{~h} . \mathrm{H}_{2} \mathrm{O}(50 \mu \mathrm{L})$ containing each substrate $(5 \mu \mathrm{mol})$ was added to a tube in a glove box. The tube was then evacuated at $77 \mathrm{~K}$ for $1 \mathrm{~h}$, and the spectrum recorded in the same manner (spectra iii and iv). 


\section{Discussion}

\section{Photocatalytic Mechanism on $\mathrm{TiO}_{2}$}

Oxygen radical. Photocatalytic reaction of substrates on bulk $\mathrm{TiO}_{2}$ suspended in water proceeds even in the absence of molecular oxygen $\left(\mathrm{O}_{2}\right)$. For example, conversions of 21, obtained following $0.5 \mathrm{~h}$ photoirradiation, are $46 \%$ (in the presence of $\mathrm{O}_{2}$; Figure $2 \mathrm{C}$ ) and $39 \%$ (under $\mathrm{N}_{2}$ saturated condition), suggesting that both $\mathrm{H}_{2} \mathrm{O}$ and $\mathrm{O}_{2}$ are oxygen source in this photooxidation system. In the presence of mannitol $(100 \mu \mathrm{mol})$, a typical $\cdot \mathrm{OH}$ radical quencher, the conversion of 21 (in the presence of $\mathrm{O}_{2}$ ) was decreased to $2 \%$, indicating that the present catalytic system involves $\cdot \mathrm{OH}$ radical as the crucial oxidant. The photocatalytic mechanism on bulk $\mathrm{TiO}_{2}$ can be summarized as below. ${ }^{5}$

The $\cdot \mathrm{OH}$ radicals are formed via reaction of the valence band holes with either adsorbed $\mathrm{H}_{2} \mathrm{O}$ or surface $\mathrm{OH}^{-}$groups on $\mathrm{TiO}_{2}$ (eqs. 1-3).

$$
\begin{aligned}
& \mathrm{TiO}_{2} \stackrel{h v}{\longrightarrow} \mathrm{h}_{\mathrm{VB}}{ }^{+}+\mathrm{e}_{\mathrm{CB}}^{-} \\
& \mathrm{h}_{\mathrm{VB}}{ }^{+}+\mathrm{H}_{2} \mathrm{O} \text { (adsorbed) } \rightarrow \cdot \mathrm{OH}+\mathrm{H}^{+} \\
& \mathrm{h}_{\mathrm{VB}^{+}}+\mathrm{OH}^{-} \text {(surface) } \rightarrow \cdot \mathrm{OH}
\end{aligned}
$$

$\mathrm{O}_{2}$ is reduced by the conduction band electron to form superoxide anion, $\mathrm{O}_{2} \cdot^{-}$(eq. 4).

$$
\mathrm{O}_{2}+\mathrm{e}_{\mathrm{CB}}^{-} \rightarrow \mathrm{O}_{2} \cdot{ }^{-}
$$

$\mathrm{H}_{2} \mathrm{O}_{2}$ is formed from $\mathrm{O}_{2} \cdot{ }^{-}$via reactions of eqs. 6 and 7.

$$
\begin{aligned}
& \mathrm{O}_{2} \cdot{ }^{-}+\mathrm{H}^{+} \leftrightarrow \mathrm{HO}_{2} \cdot \\
& \mathrm{HO}_{2} \cdot+\mathrm{HO}_{2} \cdot \rightarrow \mathrm{H}_{2} \mathrm{O}_{2}+\mathrm{O}_{2} \\
& \mathrm{O}_{2} \cdot{ }^{-}+\mathrm{HO}_{2} \cdot+\mathrm{H}^{+} \rightarrow \mathrm{H}_{2} \mathrm{O}_{2}+\mathrm{O}_{2}
\end{aligned}
$$

Cleavage of $\mathrm{H}_{2} \mathrm{O}_{2}$ produces $\cdot \mathrm{OH}$ radical via reactions of eqs. 8 and 9.

$$
\begin{aligned}
& \mathrm{H}_{2} \mathrm{O}_{2}+\mathrm{e}_{\mathrm{CB}}^{-} \rightarrow \cdot \mathrm{OH}+\mathrm{OH}^{-} \\
& \mathrm{H}_{2} \mathrm{O}_{2}+\mathrm{O}_{2} \cdot{ }^{-} \rightarrow \cdot \mathrm{OH}+\mathrm{OH}^{-}+\mathrm{O}_{2}
\end{aligned}
$$

Reaction mechanism. In the photocatalytic reaction of $\mathbf{2 1}$ on bulk $\mathrm{TiO}_{2}$, the $\cdot \mathrm{OH}$ radical, formed via the above mechanisms, reacts with the benzene ring of $\mathbf{2 1}$ to produce $\mathbf{1 0}$ with $-\mathrm{Cl}$ 
abstraction, as an initial step (Figure S4). ${ }^{6}$ The benzene ring of $\mathbf{1 0}$ is attacked subsequently by another $\cdot \mathrm{OH}$ radicals to form further-oxidized products. ${ }^{6}$ When $\mathbf{1 0}$ was used as a starting material for photocatalytic reaction on bulk $\mathrm{TiO}_{2}$ and the products, obtained by extraction with dichloromethane $(30 \mathrm{~mL} \times 3)$ from the resulting aqueous solution, were analyzed by GC/MS, trace amount of 1,2,4,5-tetrahydroxybenzene $\mathbf{2 6}$ was detected, while no other products containing benzene ring was detected. The photodecomposition of $\mathbf{1 0}$ may therefore proceed via the ring cleavage of the intermediately-formed 26 (Figure S4).

In the reaction of both $\mathbf{1 9}$ and $\mathbf{2 3}$ on bulk $\mathrm{TiO}_{2}$, substitution of $-\mathrm{Cl}$ by $-\mathrm{OH}$, on the para position of their phenolic ring, occurs to produce $\mathbf{2 1}$ as a first step (Figure S5), ${ }^{6}$ where the yield of $\mathbf{2 1}$ following $2 \mathrm{~h}$ photoirradiation is $8 \%$ (for $\mathbf{1 9}$ ) and 5\% (for $\mathbf{2 3}$ ), respectively. The formed $\mathbf{2 1}$ is successively attacked by $\cdot \mathrm{OH}$ radical to produce $\mathbf{1 0}$, which is then transformed into further-oxidized products, as shown in Figure S4.

\section{Photocatalytic Mechanism on Titanosilicate Molecular Sieve}

Oxygen radical. When the photocatalytic reaction of 21 on TS-1 was performed in water in the absence of $\mathrm{O}_{2}$, almost no conversion of $\mathbf{2 1}$ occurred, suggesting that $\mathrm{O}_{2}$ is necessary for this catalytic system. On the isolated $\mathrm{Ti}^{-} \mathrm{O}_{4}$ species with photoirradiation in the presence of $\mathrm{O}_{2}$, two types of reactive oxygen radicals, such as $\mathrm{O}_{2} \cdot{ }^{-}$and $\mathrm{O}_{3} \cdot^{-}$, are formed. ${ }^{7}$ When TS-1 was photoirradiated at $77 \mathrm{~K}$ in the presence of $\mathrm{O}_{2}$ (1 Torr), complicated ESR signals were observed (Figure S6a). In this spectrum, the $\mathrm{Ti}^{3+}$ signal, which is observed in the spectrum obtained in vacuo (Figure 3i, A), disappeared completely. The total spectrum of Figure S6a is attributed to $\mathrm{O}_{2} \cdot^{-}\left(\mathrm{g}_{\mathrm{xx}}=\right.$ 2.003, $\left.\mathrm{g}_{\mathrm{yy}}=2.009, \mathrm{~g}_{\mathrm{zz}}=2.026\right)$ and T-type $\mathrm{O}_{3} \cdot{ }^{-}\left(\mathrm{g}_{\|}=2.008, \mathrm{~g}_{\perp}=2.002\right)$ signals. $^{7}$ As reported, ${ }^{7}$ when the ESR sample was left to stand at room temperature for $1.5 \mathrm{~min}$, the $\mathrm{O}_{3}{ }^{-}$signal disappeared and only the $\mathrm{O}_{2} \cdot{ }^{-}$signal remained (Figure S6b). This results because $\mathrm{O}_{3} \cdot{ }^{-}$is unstable at room temperature, while $\mathrm{O}_{2}{ }^{-}$is stable even at room temperature. By subtracting the spectrum b from a, the disappeared $\mathrm{O}_{3} \cdot{ }^{-}$signal can be derived (spectrum c). The relative quantity of $\mathrm{O}_{2} \cdot{ }^{-}$and $\mathrm{O}_{3} \cdot{ }^{-}$can be determined by the double integration of the ESR signals, $\mathrm{b}$ and $\mathrm{c}$, respectively. The 
ratio of $\mathrm{O}_{2}{ }^{-} / \mathrm{O}_{3} \cdot{ }^{-}$was therefore estimated to be $0.75 / 0.25(=3.0)$ (total quantity $=1$ ), suggesting that, as shown in Figure S7, the reaction of the excited state $\left[\mathrm{Ti}^{3+}-\mathrm{O}_{L}{ }^{-}\right]^{*}$ active species (II) with $\mathrm{O}_{2}$ produce two types of active oxygen radical species (III and IV). ${ }^{7}$

Considering the presence of $\mathrm{H}_{2} \mathrm{O}$ in this photocatalytic system, the formed $\mathrm{O}_{2} \cdot{ }^{-}$may possibly be disproportionated by $\mathrm{H}_{2} \mathrm{O}$ to form $\mathrm{H}_{2} \mathrm{O}_{2}$, via the reactions of eqs. 5-7. When the aqueous solution, recovered following the photocatalytic reaction of $\mathbf{2 1}$ on TS-1, was analyzed by a potential difference titration of $\mathrm{Ce}^{3+} / \mathrm{Ce}^{4+}\left(0.1 \mathrm{M}\right.$ of aqueous $\left.\mathrm{Ce}\left(\mathrm{NH}_{4}\right)_{4}\left(\mathrm{SO}_{4}\right)_{4} \cdot 2 \mathrm{H}_{2} \mathrm{O}\right)$, formation of $\mathrm{H}_{2} \mathrm{O}_{2}$ was scarcely detected. Photoirradiation of TS-1 sample in the presence of $\mathrm{O}_{2}$ (1 Torr) and $\mathrm{H}_{2} \mathrm{O}$ (1 Torr) also showed similar ESR spectrum (Figure S8a) as that obtained in the presence of only $\mathrm{O}_{2}$ (Figure $\mathrm{S} 6 \mathrm{a}$ ). If $\mathrm{H}_{2} \mathrm{O}_{2}$ is produced in this catalytic system, $\cdot \mathrm{OH}$ radical may possibly be formed via the reaction with $\mathrm{O}_{2} \cdot{ }^{-}$(eq. 9). However, the appearance of $\cdot \mathrm{OH}$ radical was not confirmed in the ESR spectrum (Figure S8a), suggesting that the quantity of $\cdot \mathrm{OH}$ radical formed (even if formed) is negligibly small as compared to that of $\mathrm{O}_{2} \cdot{ }^{-}$and $\mathrm{O}_{3} \cdot{ }^{-}$. Therefore, in this catalytic system, $\mathrm{O}_{2} \cdot{ }^{-}$or $\mathrm{O}_{3} \cdot{ }^{-}$may act as the crucial oxidant.

The double integration of the total ESR spectrum (Figure S8a) indicated that the total quantity of these oxygen radical species is 0.42 , which is less than half that obtained in the absence of $\mathrm{H}_{2} \mathrm{O}$ (total quantity $=1$ ). This is owing to the deactivation of $\left[\mathrm{Ti}^{3+}-\mathrm{O}_{L}{ }^{-}\right]^{*}$ by $\mathrm{H}_{2} \mathrm{O}$. When the TS-1 sample (Figure S8a) was left to stand at room temperature for $1.5 \mathrm{~min}$, disappearance of $\mathrm{O}_{3} .^{-}$ signal was also observed (Figure S8b), suggesting that $\mathrm{O}_{3} \cdot{ }^{-}$is less stable than $\mathrm{O}_{2} \cdot{ }^{-}$in the presence of $\mathrm{H}_{2} \mathrm{O}$, as is also in the absence of $\mathrm{H}_{2} \mathrm{O}$ (Figure S6b). It is necessary to determine the crucial oxygen radical species in the present photocatalytic system. To evaluate the correct quantities of $\mathrm{O}_{2} \cdot{ }^{-}$and $\mathrm{O}_{3}{ }^{-}$radicals, formed from $\mathrm{O}_{2}$ by photoirradiation in the presence of $\mathrm{H}_{2} \mathrm{O}$, the pure $\mathrm{O}_{2} \cdot^{-}$ and $\mathrm{O}_{3} \cdot{ }^{-}$spectra (Figure S6, b and c) were summed up with weighting factors, $\alpha$ and $\beta$, to produce a simulated spectrum, as below:

$$
\text { Simulated spectrum }=\frac{\operatorname{spectrum}\left(\mathrm{O}_{2} \cdot{ }^{-}\right)}{0.75} \times \alpha+\frac{\operatorname{spectrum}\left(\mathrm{O}_{3} \cdot{ }^{-}\right)}{0.25} \times \beta
$$




$$
\alpha+\beta=0.42
$$

By trial-and-error method, the values of $\alpha(0.33)$ and $\beta(0.09)$, which produce the nearest-shaped spectrum (Figure S8c) to the observed spectrum (Figure S8a), were determined. The ratio of $\mathrm{O}_{2} \cdot{ }^{-} / \mathrm{O}_{3} \cdot{ }^{-}$was therefore estimated to be $0.33 / 0.09(=3.67)$ (total quantity $=0.42$ ), which is obviously higher than that obtained in the absence of $\mathrm{H}_{2} \mathrm{O}(0.75 / 0.25(=3))$. The results clearly suggest that, in the presence of $\mathrm{H}_{2} \mathrm{O}$, more $\mathrm{O}_{2} \cdot{ }^{-}$is formed than $\mathrm{O}_{3} \cdot{ }^{-}$, and $\mathrm{O}_{2} \cdot{ }^{-}$is more stable than $\mathrm{O}_{3} \cdot{ }^{-}$. These findings indicate that the present photocatalytic reaction on the titanosilicate molecular sieves may involve $\mathrm{O}_{2} \cdot{ }^{-}$(Figure $\mathrm{S} 7 \mathrm{III}$ ) as the crucial oxidation radical.

Reaction mechanism. $\mathrm{O}_{2} \cdot{ }^{-}$itself is inactive for chloro-substituted aromatics, whereas nucleophilic substitution of $\mathrm{O}_{2} \cdot{ }^{-}$on alkyl halides occurs effectively. ${ }^{8}$ The direct substitution of $-\mathrm{Cl}$ by $-\mathrm{OH}$ group, by the $\mathrm{O}_{2} \cdot{ }^{-}$formed, can therefore be ruled out of the reaction pathway of $\mathbf{2 1}$ to $\mathbf{1 0}$ in the present catalytic system. Considering the electrophilic character of $\mathrm{O}_{L}{ }^{-}$, formed by photoinduced charge transfer from $\mathrm{O}_{L}{ }^{2-}$ to $\mathrm{Ti}^{4+}$, an electron transfer from $\mathbf{2 1}$ to $\mathrm{O}_{L}^{-}$may possibly occur. It is reported that, ${ }^{7}$ in the photocatalytic reaction of propene on the $\mathrm{Ti}^{\mathrm{O}} \mathrm{O}_{4}$ species, several radical species, derived from propene, are formed by the electron transfer from propene to $\mathrm{O}_{L}{ }^{-}$. However, photoirradiation of TS-1 sample with substrate in the absence of $\mathrm{O}_{2}$ (Figure 3iv, A) did not show any ESR signals other than $\mathrm{Ti}^{3+}$ and $\mathrm{O}_{L}^{-}$, suggesting that any radical species derived from substrate do not form in the present catalytic system. This may possibly be because nucleophilicity of phenolic substrate, used in the present study, is lower than that of olefin. The decrease in the $\mathrm{Ti}^{3+}$ signal on TS-1 in the presence of substrate (Figure 3iv, A) may therefore be attributed to the formation of $\pi-\mathrm{O}_{L}$ type complex (Figure S7V) between $\pi$ electron on the benzene ring of 21 and electrophilic $\mathrm{O}_{L}^{-}$. The formation of this complex may destabilize $\mathrm{Ti}^{3+}$, thus resulting in the decrease in the $\mathrm{Ti}^{3+}$ signal (Figure 3iv, A). This nonradical complex is expected naturally to be very weak, such that the formation of the complex might therefore be preferable for substrate having a size close to the pore of the catalyst, whose motion is restricted sterically by the pore wall. The formation of $\mathbf{1 0}$ may therefore occur as shown in Figure S7: (i) via reaction of the 
electrophilic $\pi-\mathrm{O}_{L}$ type intermediate of $\mathbf{2 1}$ on the species $\mathrm{V}$ with the nucleophilic $\mathrm{O}_{2}{ }^{-}$on the species III and/or (ii) via reaction of these species formed on the same [Ti-O] site (species VI), followed by reaction with $\mathrm{H}_{2} \mathrm{O}$ (substitution of $-\mathrm{Cl}$ by $-\mathrm{OH}$ group). This mechanism, involving the formation of the weak $\pi-\mathrm{O}_{L}$ type complex, can explain the onset mechanism for the precise "size-screening" photocatalytic activity of the titanosilicate molecular sieves containing the isolated $\mathrm{Ti}^{-} \mathrm{O}_{4}$ species, as shown in Figure 2, A and B.

During both photocatalytic reactions of $\mathbf{1 9}$ and $\mathbf{2 3}$ on TS-1, the formation of $\mathbf{2 1}$ was detected. However, 4-chlorocatechol (14) and 4-chlororesorcinol (6) were not detected in the reaction of 19 and 23, respectively. This suggests that, on the $\mathrm{Ti}-\mathrm{O}_{4}$ species, substitution of $-\mathrm{Cl}$ by $-\mathrm{OH}$ on the para position of the phenolic ring of $\mathbf{1 9}$ and $\mathbf{2 3}$ occurs preferentially, and both transformations of 19 and 23 into 10 proceed via 21 , as also in the photocatalytic reaction on bulk $\mathrm{TiO}_{2}$ (Figure S5). As shown in Figure S9, the quantity of $\mathbf{2 1}$ during the reaction of $\mathbf{1 9}$ and $\mathbf{2 3}$ (initial: $20 \mu \mathrm{mol}$ ) on TS-1 is significantly low $(<1.4 \mu \mathrm{mol})$. This indicates that the formed $\mathbf{2 1}$ is immediately transformed into $\mathbf{1 0}$ within the pore of the catalyst. 


\section{Tables}

Table S1. Properties of photocatalysts used.

\begin{tabular}{|c|c|c|c|c|c|}
\hline & pore dimension $(\mathrm{nm})$ & $\begin{array}{l}\text { Ti content }(=\mathrm{Ti} /(\mathrm{Ti}+\mathrm{Si})) \\
(\mathrm{mol} \%)\end{array}$ & $\begin{array}{l}\text { BET surface area } \\
\left(\mathrm{m}^{2} / \mathrm{g}\right)\end{array}$ & $\begin{array}{l}\text { external surface } \\
\text { area }\left(\mathrm{m}^{2} / \mathrm{g}\right)^{a}\end{array}$ & $\begin{array}{l}\text { monolayer adsorption capacity of } \\
\mathrm{H}_{2} \mathrm{O}\left(\text { molecules } / \mathrm{nm}^{2}\right)^{b}\end{array}$ \\
\hline \multirow[t]{4}{*}{ TS-1 } & $0.54 \times 0.56$ & 0.39 & 385 & 7.5 & 0.80 \\
\hline & (sinusoid channel) & & & & \\
\hline & $0.52 \times 0.58$ & & & & \\
\hline & (straight channel) & & & & \\
\hline TS-2 & $0.53 \times 0.54$ & 0.41 & 329 & 26.6 & 0.97 \\
\hline $\mathrm{TiO}_{2}$ & & 100 & 48 & & 6.50 \\
\hline \multirow[t]{4}{*}{ S-1 } & $0.54 \times 0.56$ & & 392 & 14.2 & 0.77 \\
\hline & (sinusoid channel) & & & & \\
\hline & $0.52 \times 0.58$ & & & & \\
\hline & (straight channel) & & & & \\
\hline $\mathrm{TiO}_{2} / \mathrm{S}-1$ & & 5.10 & 344 & 15.5 & 1.34 \\
\hline TS- $1^{\text {high }}$ & & 5.30 & 338 & 18.2 & 1.20 \\
\hline $\mathrm{Ti}-\mathrm{SiO}_{2}$ & & 0.44 & 99 & & 8.87 \\
\hline
\end{tabular}

${ }^{a}$ determined by $t$-plot volumetric measurements with $\mathrm{N}_{2} \cdot{ }^{b}$ determined by dividing the amount of $\mathrm{H}_{2} \mathrm{O}$ adsorbed on the materials by the BET surface area of the respective materials. ${ }^{9}$ 
Table S2. EMW, half-wave oxidation potential $\left(E_{1 / 2}^{o x}\right)$, HOMO level, log $P$, distribution ratio $(D)$, and photoconversion of substrates.

\begin{tabular}{|c|c|c|c|c|c|c|c|c|c|c|c|}
\hline \multirow[b]{2}{*}{ No. } & \multirow[b]{2}{*}{ substrate } & \multirow{2}{*}{$\begin{array}{l}\text { EMW } \\
(\mathrm{nm})\end{array}$} & \multirow[b]{2}{*}{$E_{1 / 2}^{o x}(\mathrm{~V})^{a}$} & \multirow{2}{*}{$\begin{array}{l}\text { HOMO level } \\
\qquad(\mathrm{eV})^{b}\end{array}$} & \multirow[b]{2}{*}{$\log P^{c}$} & \multicolumn{2}{|c|}{ TS-1 } & \multicolumn{2}{|c|}{ TS-2 } & \multicolumn{2}{|c|}{$\mathrm{TiO}_{2}$} \\
\hline & & & & & & $D^{d}$ & conv. $^{e}$ & $D^{d}$ & conv. $^{e}$ & $D^{d}$ & conv. $^{e}$ \\
\hline 1 & hydroquinone & 0.5097 & 1.09 & 0.173 & 0.89 & 0.18 & 0 & 0.1 & 0 & 0.07 & 44.9 \\
\hline 2 & benzyl alcohol & 0.5111 & 1.38 & 0.138 & 1.02 & 5.35 & 0 & 1.68 & 0.2 & 0.01 & 46.7 \\
\hline 3 & phenol & 0.5134 & 1.60 & 0.292 & 1.64 & 0.37 & 0 & 0.2 & 0.4 & 0 & 48 \\
\hline 4 & 4-chlorophenol & 0.5244 & 1.65 & 0.049 & 2.43 & 2.84 & 0.3 & 1.6 & 0.5 & 0.01 & 41 \\
\hline 5 & $p$-cresol & 0.5329 & 1.49 & 0.330 & 2.13 & 1.81 & 0.1 & 1.07 & 0.4 & 0.86 & 28 \\
\hline 6 & 4-chlororesorcinol & 0.5400 & 1.20 & 0.000 & 1.81 & 0 & 0 & 0 & 0 & 0 & 22 \\
\hline 7 & 2-chlorophenol & 0.5414 & 1.71 & 0.029 & 2.16 & 2.7 & 0.3 & 1.32 & 0.1 & 0.04 & 55.9 \\
\hline 8 & 3-chlorocatechol & 0.5664 & 1.76 & -0.100 & 1.81 & 2.12 & 0.1 & 2.01 & 1.4 & 0 & 31 \\
\hline 9 & resorcinol & 0.5758 & 1.19 & 0.270 & 0.8 & 0.03 & 3.3 & 0.01 & 2.2 & 0 & 38 \\
\hline 10 & 1,2,4-trihydroxybenzene & 0.5762 & 0.97 & 0.137 & 0.87 & 0 & 0.6 & 0 & 0.3 & 0.98 & 25.5 \\
\hline 11 & 3-chlorophenol & 0.5775 & 1.76 & -0.100 & 2.5 & 3.57 & 2.5 & 1.56 & 1.7 & 0.02 & 67.5 \\
\hline 12 & 1,2,3-trihydroxybenzene & 0.5778 & 0.99 & 0.210 & 0.87 & 1.1 & 1.1 & 1.14 & 1.5 & 0.05 & 44.2 \\
\hline 13 & 2,5-dichlorophenol & 0.5810 & 1.97 & -0.262 & 2.76 & 9.32 & 3.2 & 4.51 & 2.5 & 0.13 & 22 \\
\hline 14 & 4-chlorocatechol & 0.5817 & 1.81 & -0.047 & 1.81 & 2.4 & 1.4 & 2.6 & 2 & 0.03 & 34 \\
\hline 15 & catechol & 0.5832 & 1.22 & 0.205 & 0.91 & 0 & 2 & 0 & 2.1 & 0 & 52.1 \\
\hline 16 & $m$-cresol & 0.5873 & 1.59 & 0.284 & 2 & 3.48 & 2.5 & 1.37 & 3.1 & 0.43 & 20.2 \\
\hline 17 & 2,6-dichlorophenol & 0.6032 & 1.88 & -0.247 & 2.76 & 0.02 & 6.2 & 0.02 & 4.5 & 2.86 & 8.2 \\
\hline 18 & 3,5-dichlorophenol & 0.6036 & 1.74 & -0.271 & 3.54 & 0.04 & 2.2 & 0.01 & 2.5 & 0 & 35 \\
\hline 19 & 2,4-dichlorophenol & 0.6051 & 1.79 & -0.183 & 3.26 & 2.6 & 7.1 & 0.91 & 6.6 & 0.08 & 53 \\
\hline 20 & 1,3,5-trihydroxybenzene & 0.6132 & 1.36 & 0.256 & 0.87 & 0 & 14.8 & 0 & 10.9 & 0.21 & 47.7 \\
\hline 21 & 2-chlorohydroquinone & 0.6149 & 1.21 & -0.087 & 1.81 & 0.05 & 13.2 & 0 & 13.8 & 0 & 45.5 \\
\hline 22 & 5-chlororesorcinol & 0.6357 & 1.68 & -0.001 & 1.81 & 0 & 4.1 & 0 & 3.2 & 0 & 49 \\
\hline 23 & 3,4-dichlorophenol & 0.6431 & 1.65 & -0.216 & 2.76 & 0.5 & 6.2 & 0.09 & 5.8 & 0.2 & 26 \\
\hline 24 & 2,6-bis(hydroxymethyl)-p-cresol & 0.6872 & 1.51 & 0.117 & 0.98 & 0 & 0.3 & 0 & 0 & 0 & 50.7 \\
\hline 25 & 2,4,6-trichlorophenol & 0.7034 & 1.84 & -0.441 & 3.87 & 0 & 0 & 0 & 0 & 0 & 29 \\
\hline
\end{tabular}

${ }^{a}$ vs. $\mathrm{Ag} / \mathrm{AgCl}$ (in acetonitrile with $\mathrm{TBABF}_{4}{ }^{-}$). ${ }^{b}$ calculated by WinMOPAC ver.3.0 (Fujitsu Inc.). ${ }^{c}$ calculated by ChemDraw Ultra ver.7.0.1 (CambridgeSoft Corp.). ${ }^{d} D=\left(C_{0}-C_{\mathrm{e}}\right) / C_{\mathrm{e}}$, where $C_{0}$ denote initial concentration of substrate in water and $C_{\mathrm{e}}$ denote equilibrium concentration of substrate in water after stirring with catalyst (time, $0.5 \mathrm{~h}$; temperature, $313 \mathrm{~K}$ ). ${ }^{e}$ photoirradiation time, $0.5 \mathrm{~h}$ (the same data as those in Figure 2 ). 


\section{Figures}

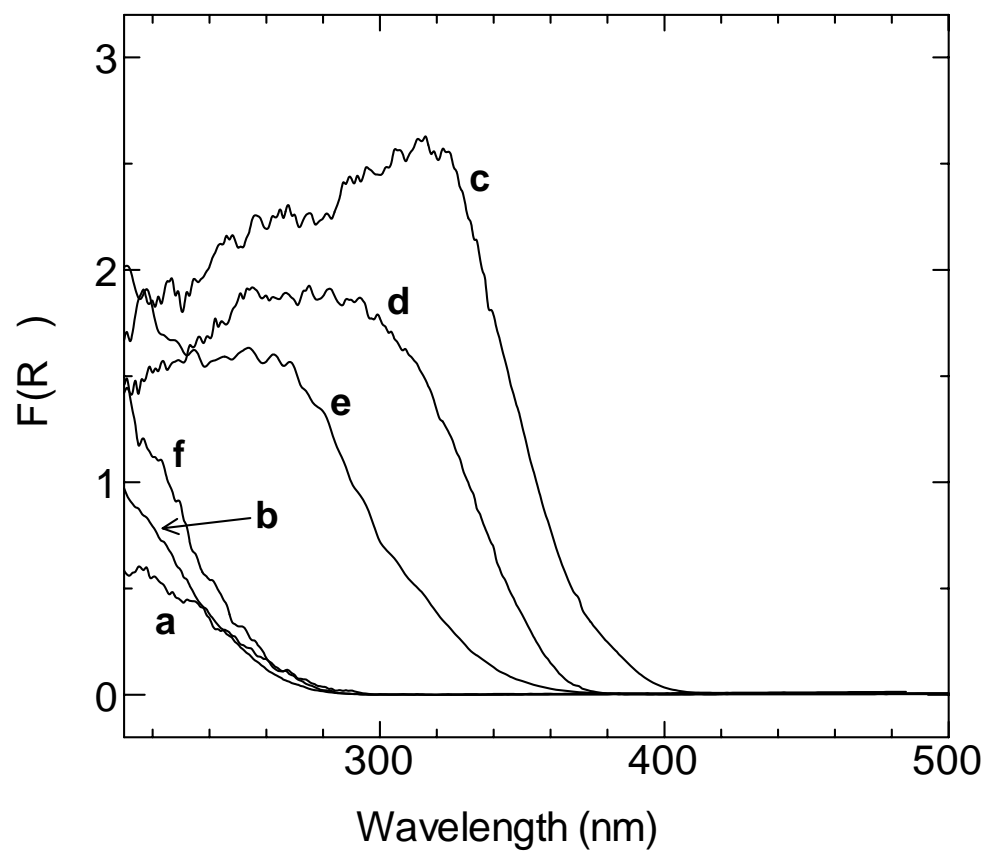

Figure S1. Diffuse reflectance spectra of (a) TS-1, (b) TS-2, (c) $\mathrm{TiO}_{2}$, (d) $\mathrm{TiO}_{2} / \mathrm{S}-1$, (e) TS-1 ${ }^{\text {high }}$, and (f) $\mathrm{Ti}_{-} \mathrm{SiO}_{2}$ catalysts.

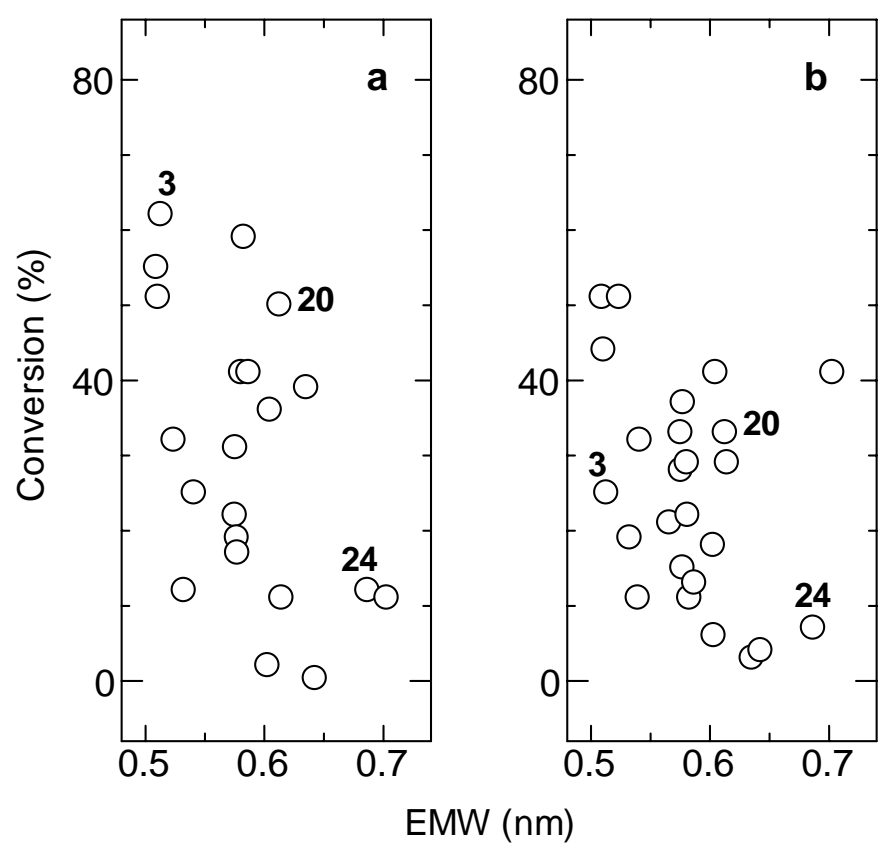

Figure S2. Relation between EMW and photoconversion $(0.5 \mathrm{~h})$ of substrates on $(\mathbf{a}) \mathrm{TiO}_{2} / \mathrm{S}-1$ and (b) TS-1 ${ }^{\text {high }}$ catalysts. The substrates used are 1-25. 


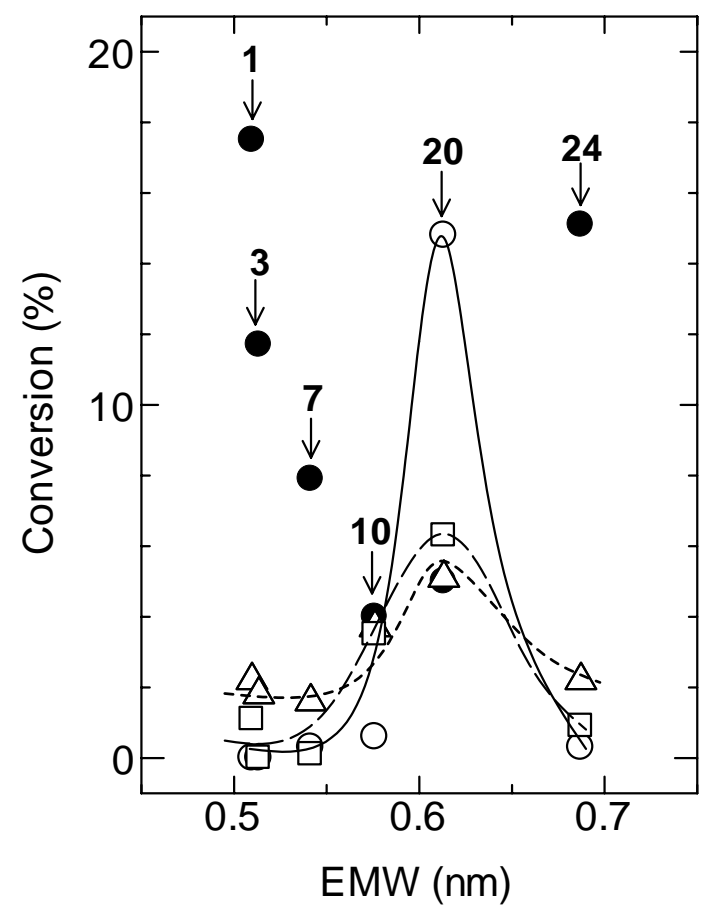

Figure S3. Photoconversion ( $0.5 \mathrm{~h})$ of substrates on TS-1 in acetonitrile of different $\mathrm{H}_{2} \mathrm{O}$ content. The water content is 0 (black symbol), 10 (triangle symbol), 50 (square symbol), and $100 \%$ (open symbol), respectively. The substrates used are denoted in the figure as numbers.

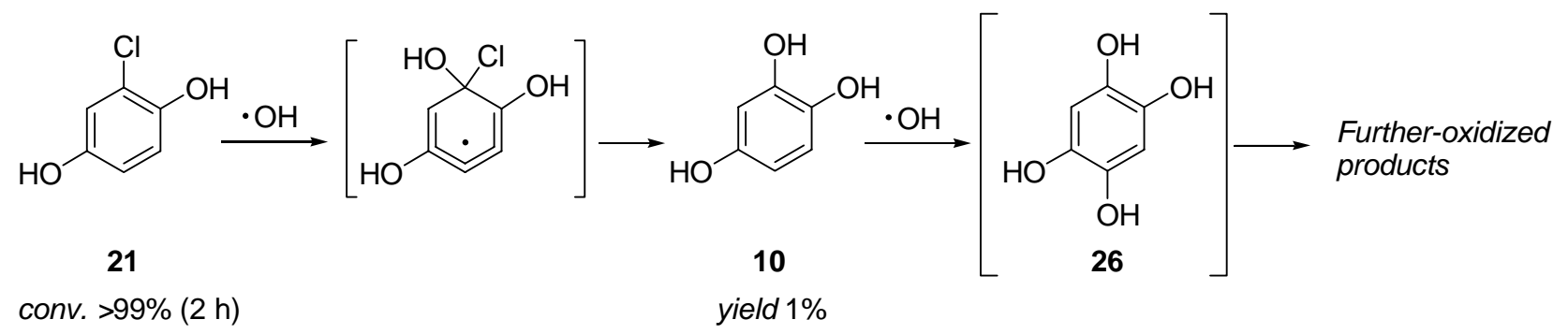

Figure S4. Reaction mechanism of 21 on bulk $\mathrm{TiO}_{2}$. 
<smiles>Oc1ccc(Cl)cc1Cl</smiles>

19

conv. $92 \%(2 \mathrm{~h})$<smiles>Oc1ccc(Cl)c(Cl)c1</smiles>

23

conv. $64 \%(2 \mathrm{~h})$
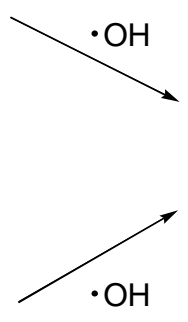

21

yield

$8 \%$ (for 19)

$5 \%$ (for 23)

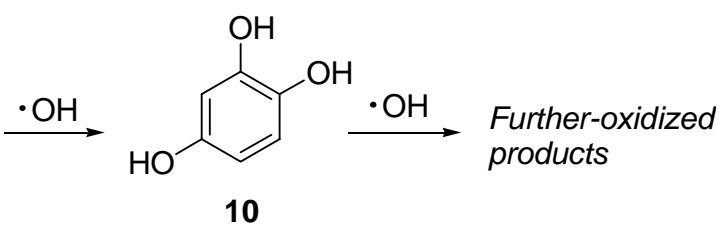

yield

$2 \%$ (for 19)

$1 \%$ (for 23)

Figure S5. Reaction mechanism of 19 and 23 on bulk $\mathrm{TiO}_{2}$.
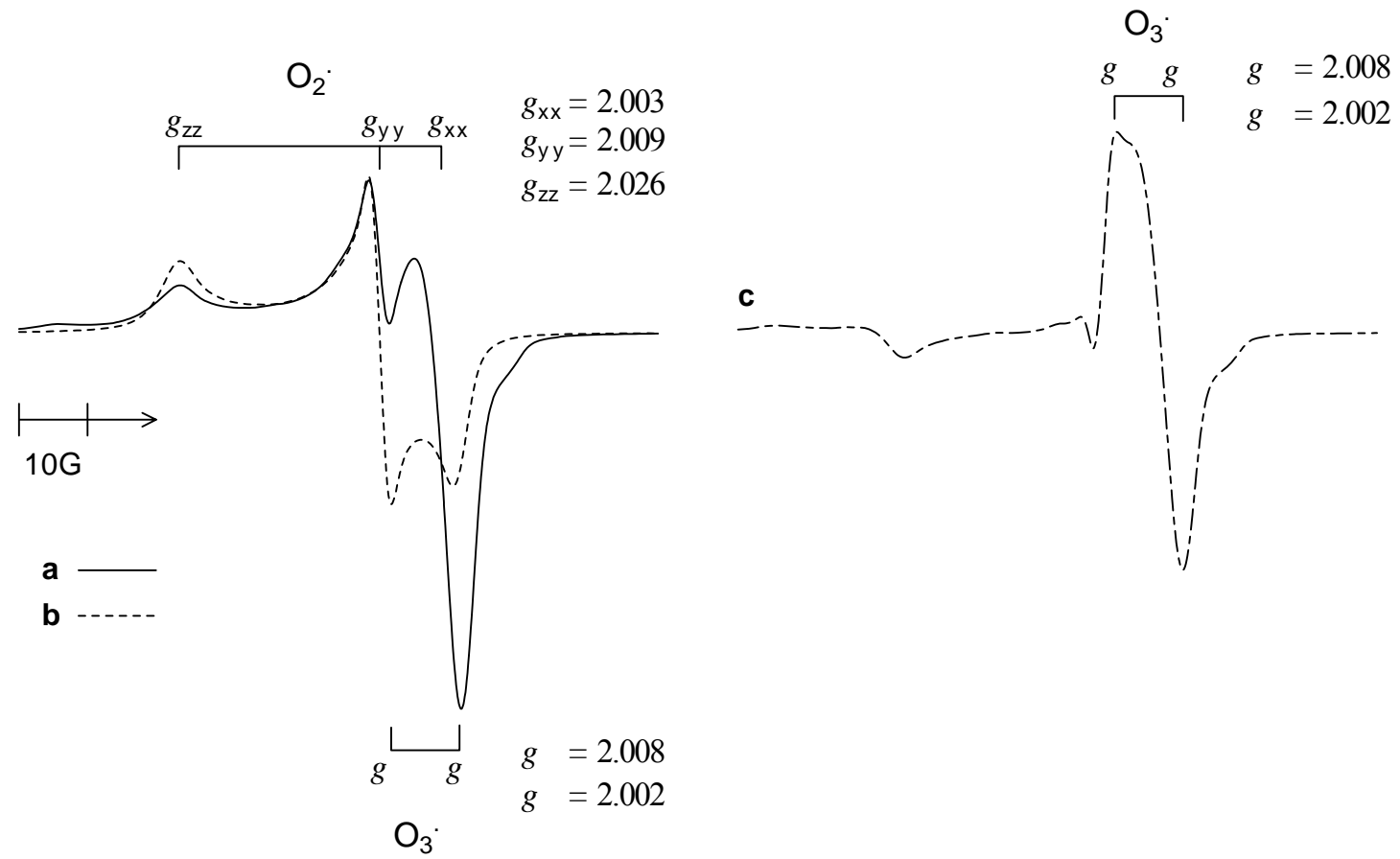

Figure S6. ESR spectra at $77 \mathrm{~K}$ of TS-1 (a) after photoirradiation in the presence of $\mathrm{O}_{2}$ (1 Torr) at $77 \mathrm{~K}$, (b) followed by letting to stand at room temperature for $1.5 \mathrm{~min}$. The spectrum (c) is obtained by subtracting the spectrum $\mathbf{b}$ from the spectrum a. The measurements were done according to the literature procedure, ${ }^{7}$ as follows. TS-1 $(50 \mathrm{mg})$ was placed in a quartz ESR tube and treated with 100 Torr oxygen $(1$ Torr $=133.3 \mathrm{~Pa})$ at $773 \mathrm{~K}$ for $12 \mathrm{~h}$. The tube was evacuated at $673 \mathrm{~K}$ for $1 \mathrm{~h}$ and cooled to room temperature. $\mathrm{O}_{2}$ (1 Torr) was then introduced to the tube. The tube was placed on an ESR sample cavity and photoirradiated at $77 \mathrm{~K}$. After photoirradiation for $0.5 \mathrm{~h}$, the irradiation was turned off, and measurement was started immediately (spectrum a). The tube was then ejected from the cavity and left to stand at room temperature for $1.5 \mathrm{~min}$. The tube was then placed on the cavity again, and measurement was started (spectrum b). 


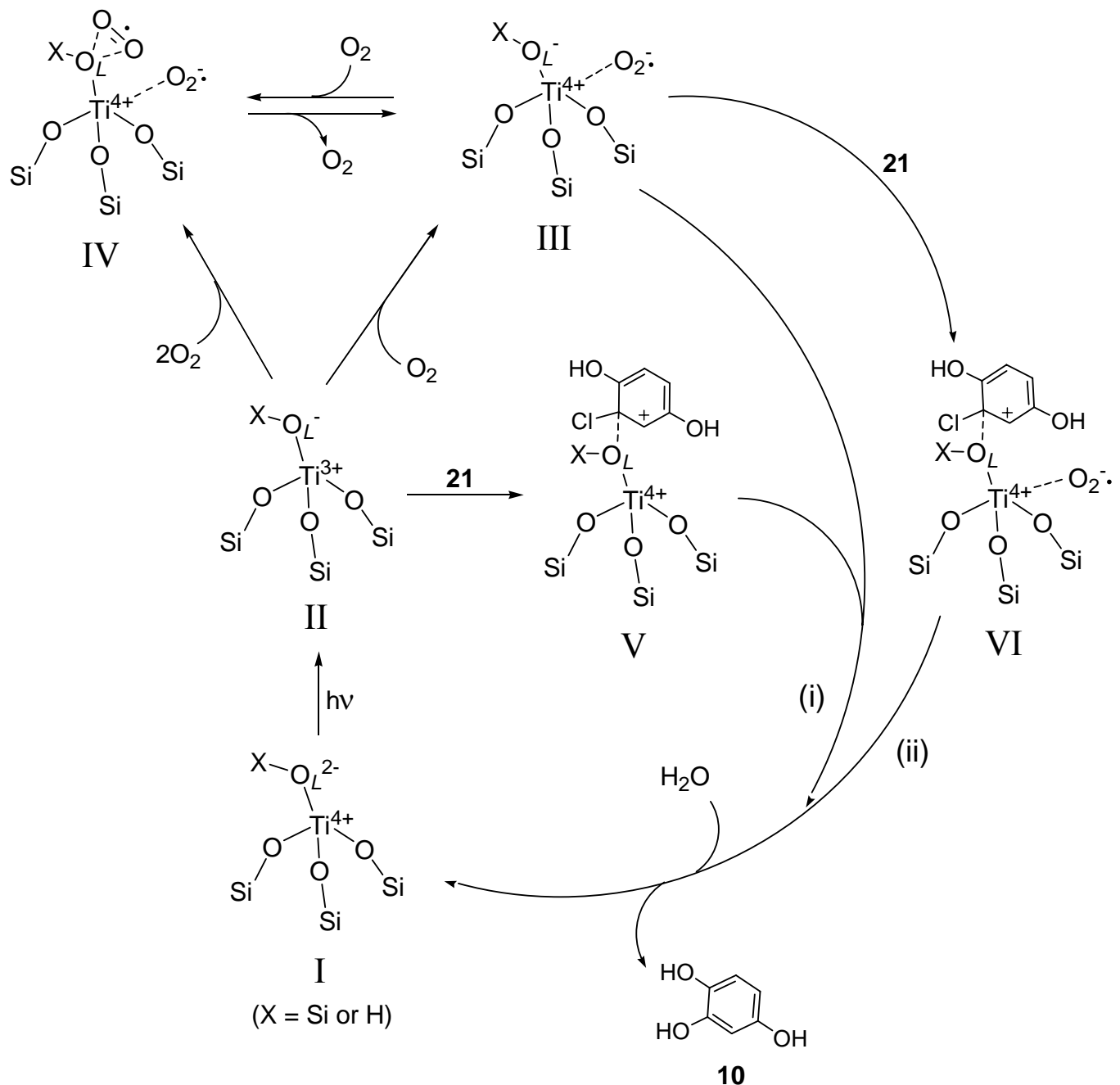

Figure S7. Reaction mechanism of $\mathbf{2 1}$ on isolated Ti-O $\mathrm{O}_{4}$ species of titanosilicate molecular sieves. 


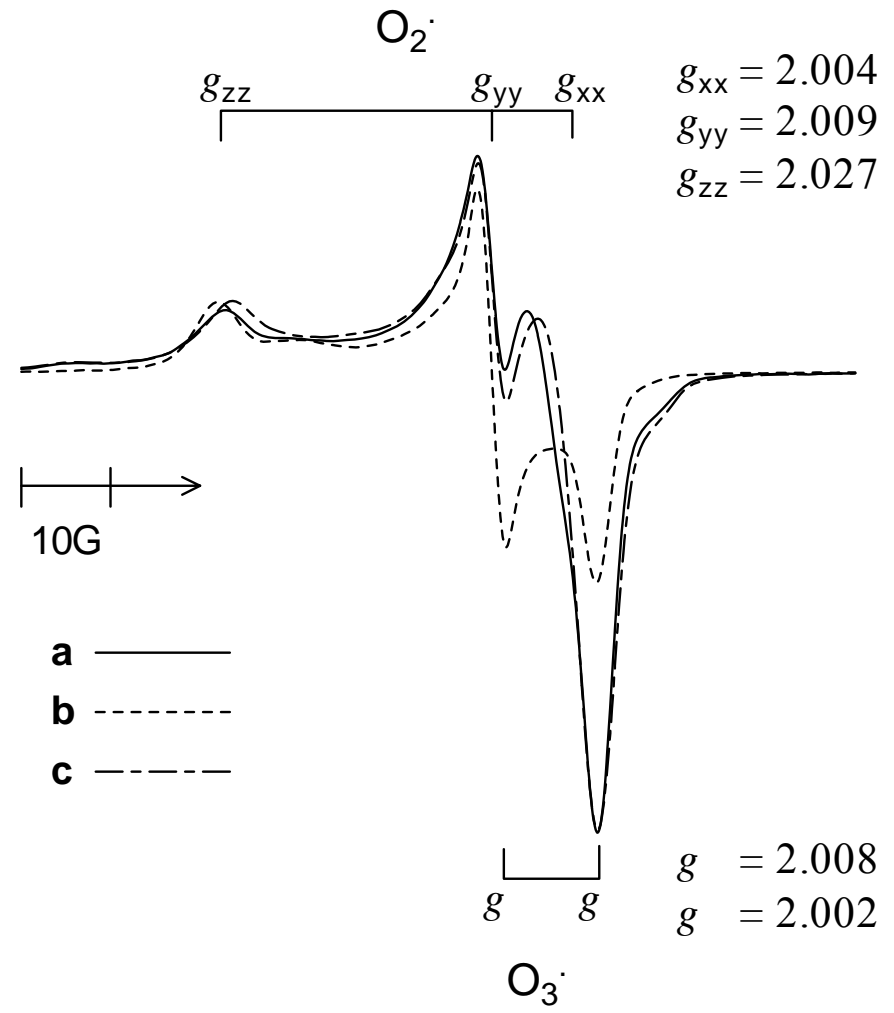

Figure S8. ESR spectra at $77 \mathrm{~K}$ of TS-1 (a) after photoirradiation in the presence of $\mathrm{O}_{2}$ (1 Torr) and $\mathrm{H}_{2} \mathrm{O}$ (1 Torr) at $77 \mathrm{~K}$, (b) followed by letting to stand at room temperature for $1.5 \mathrm{~min}$. The spectrum (c) is the simulated spectrum obtained by trial-and-error method using eqs. 10 and 11 .

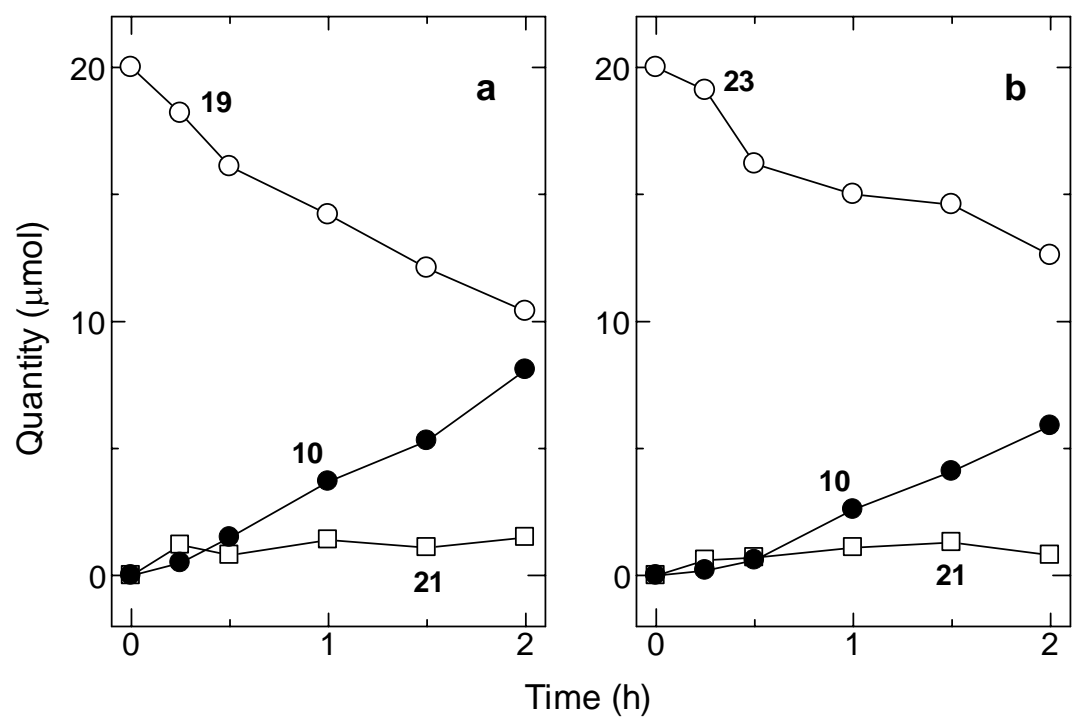

Figure 59. Time-course variation in the quantities of substrates and products during photoirradiation of TS-1 suspended in aqueous solution containing (a) 19 and (b) 23 as substrate. 


\section{References}

(1) Clerici, M. G.; Bellussi, G.; Romano, U. J. Catal. 1991, 129, 159-167.

(2) Reddy, J. S.; Kumar, R. J. Catal. 1991, 130, 440-446.

(3) Hsien, Y. -H.; Chang, C. -F.; Chen, Y. -H.; Cheng, S. Appl. Catal. B 2001, 31, 241-249.

(4) Yoshida, H.; Murata, C.; Hattori, T. Chem. Commun. 1999, 1551-1152.

(5) Al-Akabi, H.; Serpone, N.; Pelizzetti, E.; Minero, C.; Fox, M. A.; Draper, R. B. Langmuir 1989, 5, 250-255.

(6) D’Oliveira, J. -C.; Al-Sayyed, G.; Pichat, P. Environ. Sci. Technol. 1990, 24, 990-996.

(7) Murata, C.; Yoshida, H.; Kumagai, J.; Hattori, T. J. Phys. Chem. B 2003, 107, 4364-4373.

(8) Corey, E. J. Tetrahedron Lett. 1975, 16, 3183-3186.

(9) Miura, K.; Morimoto, T. Langmuir 1994, 10, 807-811. 